\title{
Ivabradine - a novel treatment for chronic stable angina
}

Janet Marianne Jackson

CSF Medical Communications, Cheltenham, UK

Drugs in Context 2012

DOI: http://dx.doi.org/10.7573/dic.212225

Citation: Jackson, JM. Ivabradine - a novel treatment for chronic stable angina. Drugs in Context: e212225. doi:10.7573/dic.212225

Copyright: this is an open access article published under the terms of the Creative Commons License Deed (CC BY-NC-ND 3.0) which allows you to share, copy, distribute and transmit the work provided it is properly attributed. You may not use this work for commercial purposes. For further information on commercial use, contact publisher@justmedicalmedia.com or go to wrwre.drugsincontext.com/copyright.

Search criteria: English language articles were identified by searching the PubMed database using the search terms 'ivabradine' and 'angina'. Abstracts were evaluated and selected for further review according to our standard protocols. Bibliographies of individual articles were also assessed for additional articles of interest and the manufacturer of ivabradine was invited to supply any additional data to that identified via the PubMed database. .

Date of last literature search: 4 April 2008.

Conclusion: Ivabradine is a new class of anti-anginal and anti-ischemic representing a novel pharmacological approach to the treatment of angina. U se of $\beta$-blockers has traditionally been first line treatment for stable angina, however, unacceptable side effects have limited their use in many patients. Because of its selective and specific mechanism of action, ivabradine has demonstrated a highly satisfactory safety profile making it a well-tolerated alternative therapy for chronic stable angina patients with normal sinus rhythm who are either intolerant of $\beta$-blockers or where their use is contraindicated.

NB: This article was originally published by CSF Medical Communications Ltd (CSF) in Drugs in Context 2008;4(2):135-52. Drugs in Context and all CSF copyrights were acquired by Just Medical Media Ltd in 2009. 


\section{SUMMARY}

Heart rate is an important determinant of myocardial oxygen consumption and elevated heart rate is a known risk factor in coronary artery disease. Heart rate reduction has been the cornerstone of antianginal and antiischemic therapy for many years and is most often achieved by $\beta$-blockers. The discovery of the f-channel and its role in regulating pacemaker activity in the sinoatrial node led to the development of new pharmacological agents such as ivabradine, which target these f-channels causing a reduction in heart rate by inhibiting the $I_{f}$ current. Due to its specific and selective action, ivabradine does not display any of the negative inotropic peripheral vascular or central nervous system side-effects that have limited the use of $\beta$-blockers in some patients. Ivabradine efficacy has been investigated in a large clinical development programme involving 5000 participants including over 3500 patients with chronic stable angina, and was shown to reduce resting and exercise induced heart rate without modifying any electrophysiological parameters. It has been shown to reduce heart rate at rest and during exercise and improve measurable parameters of angina in a dose-dependent manner. Its antiianginal and antiischemic effects have also has been shown to be non-inferior to commonly use doses of atenolol and amlodipine. Ivabradine is currently licensed for oral use at 5 and $7.5 \mathrm{mg}$ twice daily for symptomatic treatment of chronic stable angina in patients with normal sinus rhythm who are either intolerant of $\beta$-blockers or for whom they are contraindicated.

Key words: ivabradine, procorolan, angina, myocardial ischemia, heart rate

\section{CHRONIC STABLE ANGINA: A PERSPECTIVE}

Coronary heart disease is the leading cause of mortality and morbidity in European countries and chronic stable angina pectoris is a primary symptom and the first clinical manifestation in up to $50 \%$ of patients. It has been estimated that in most European countries 20,000-40,000 individuals per million of the population suffer from angina, which for many seriously affects the quality of all aspects of life and restricts daily activities. ${ }^{1}$ The prevalence of angina increases sharply with age in both sexes, but improvements in preventative measures and increased use of revascularisation have led to better prognosis and survival after acute coronary events. However, despite several clinical intervention techniques the overall prevalence of angina has increased partly due to a shift to an older age group and as the age of the population is increasing in most western countries this has become a serious health burden. ${ }^{2}$

Angina occurs when there is insufficient oxygen supply to the heart usually due to atherosclerotic coronary artery obstruction. Heart rate is a key determinant of myocardial oxygen consumption and increased heart rate is associated with most ischemic episodes in patients with coronary artery disease (CAD). Several studies have also shown that elevated resting heart rate is associated with cardiovascular disease (CVD) mortality from all causes and is also a predictive factor for survival for patients with CVD. . $^{3,4,5,6,7}$ In a large-scale study of approximately 25000 patients with suspected or proven CAD, resting heart rate was found to be a predictor of overall and cardiovascular mortality, independent of other known risk factors such as hypertension, diabetes, and smoking. A high resting heart rate of $\geq 83 \mathrm{bpm}$ was a strong predictor of cardiovascular mortality (Figure 1). ${ }^{5}$ A review of the major studies on high resting heart rate (RHR) as a cardiovascular risk factor concludes that RHR should be targeted for therapy for such patients. ${ }^{8}$

Lowering heart rate reduces cardiac work and consequently oxygen consumption, which restores the balance between myocardial oxygen 
Figure 1. Adjusted survival curves for overall mortality by resting heart rate quintiles. ${ }^{5}$

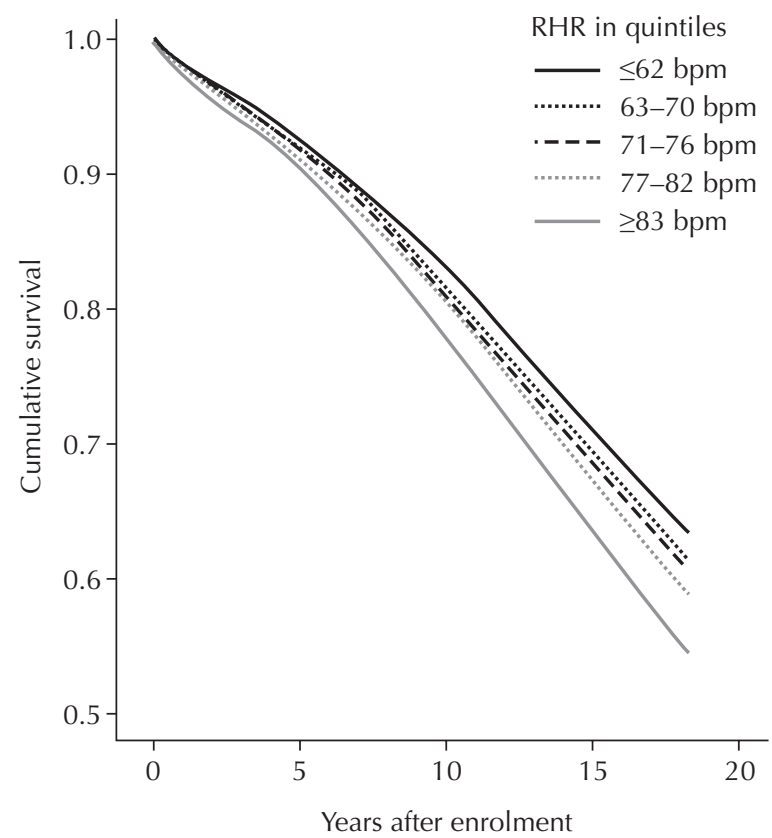

supply and demand. Reducing heart rate also increases diastolic filling time which improves myocardial perfusion and oxygen supply. Heart rate reduction is the primary focus of anti-angina and anti-ischemic therapy aimed at reducing symptoms.

Three groups of drugs have been the mainstay of medical therapy for angina for many years. These are $\beta$-blockers, calcium channel blockers and nitrates. Although $\beta$-blockers and some rate-limiting calcium channel-blockers (verapamil and diltiazem) reduce heart rate, acting consequently to decrease myocardial oxygen demand, they are non-selective and have many unwanted side effects including fatigue, and sexual dysfunction, which have implications for patient compliance and for some patients means that target doses cannot be met. Comparison of first generation (propanolol) and second generation (atenolol) $\beta$-blockers with new third generation $\beta$-blockers (nebivolol) suggests that $\beta$-blockers like atenolol are not as cardioselective as once thought and may be shorter acting. Also newer $\beta$-blockers like nebivolol have vasodilator properties which may make some unwanted side effects less likely. ${ }^{9,10}$ The beneficial effects of $\beta$-blockers in pacemaker-dependent patients with symptomatic left ventricular $(\mathrm{LV})$ systolic dysfunction, has been shown to be due to the lowering elevated heart rate. ${ }^{11}$ In a metaregression analysis of randomized clinical trials a statistically significant relationship was found between RHR reduction and the clinical benefit (reduction of cardiac, sudden death and recurrence of non-fatal $\mathrm{MI}$ ) of $\beta$-blockers and calcium channel blockers in post-MI patients, which strongly suggest that the beneficial effect is proportionally related to $\mathrm{RHR}$ reduction. ${ }^{12}$

Many patients have residual or recurrent angina even after revascularisation or experience angina while receiving medication, others are intolerant or have contraindication to traditional $\beta$-blockers, including patients with peripheral artery disease or brittle diabetes. Therefore the need was identified for a new class of drugs that could selectively reduce heart rate without affecting myocardial contractility, peripheral circulation or glucose and triglyceride metabolism, to meet shortfalls in medical care for these patients. ${ }^{2}$

Ivabradine is a new anti-ischemic antianginal agent which acts purely through heart rate reduction without affecting other cardiac functions, therefore maintaining myocardial contractility, atrioventricular conduction and ventricular repolarisation. Also there is no indirect a-stimulating activity which is responsible for the vasoconstriction seen with $\beta$-blockers. ${ }^{13-16}$ Ivabradine (Procoralan) is now available for monotherapy in Europe for symptomatic treatment of patients with chronic stable angina and normal sinus rhythm but who are intolerant to $\beta$-blockers or have a contraindication to their use. Table 1 summarises the advantages offered by ivabradine for patients with chronic stable angina. ${ }^{17}$ 
Table 1. Advantages of ivabradine in patients with angina. ${ }^{17}$

Exclusive heart rate reduction

Proven anti-ischaemic and anti-anginal properties

Absence of negative inotropic effects

Preservation of left ventricular relaxation (lack of effects on diastolic function)

Absence of coronary vasoconstriction

Preserved atrioventricular and ventricular conduction

Preservation of blood pressure

Absence of bronchospasm associated with $\beta$-blockers

\section{PHARMACOLOGY}

\section{Mechanisms of action}

\section{Selective sinus node $I_{f}$ inhibition}

Heart rate is controlled by the sinoatrial node located in the right atrium. This is where the action potential is created and is conducted to the ventricles triggering ventricular contraction. The sinoatrial myocytes are the heart's pacemaker cells. They generate an action potential by electrical depolarisation, which spreads from the sinus node through the cardiac conducting tissue in a controlled wave to coordinate cardiac contraction. This pacemaker activity controls heart rate and depends on interaction between several ionic currents involved in diastolic depolarisation. The f-channel (funny due to its unusual properties) allows sodium ions to move inwards and potassium ions to move outwards across the cell membrane through a hyperpolarisationactivated, cyclic nucleotide-gated (HCN) channel so generating the $I_{\mathrm{f}}$ current. This is the major determinant of the diastolic depolarisation slope of the sinus node. The channels are open during the diastolic depolarisation phase and closed at the peak of the action potential. ${ }^{18,19}$ Therefore, targeting the f-channel can directly affect the frequency of the action potential.

Early studies demonstrated dose-dependent inhibition of f-channels by the bradycardic agent S16257 (ivabradine) on rabbit sinoatrial node cells in vitro. ${ }^{19,20}$ At therapeutic concentrations ivabradine had no significant effect on other cardiac ionic currents or cardiac action potential shape and therefore its action was found to be selective and specific. ${ }^{20,21}$ Several agents were tested for inhibition of $I_{\mathrm{f}}$ current but ivabradine was the most specific, binding with high affinity to the f-channels, and is the only one to have reached clinical development. ${ }^{22}$ Ivabradine specifically binds to the f-channel on the intracellular side of sinoatrial pacemaker cell membrane and blocks the entry of sodium ions into the cell. This action causes selective inhibition of the $I_{\mathrm{f}}$ current, in a dose dependent manner, which plateaus at higher concentrations. Blocking the $I_{\mathrm{f}}$ current causes a reduction in the slow diastolic depolarisation slope, without affecting maximal diastolic potential or threshold activation potential, which exhibits a use-dependent effect on heart rate. (Figure $2 \mathrm{a}$ and b). ${ }^{13,23}$

\section{Pure heart rate reduction}

Heart rate reduction is a major determinant in maintaining myocardial oxygen supply. This is the common mechanism of action for $\beta$-blockers and ivabradine in anti-anginal therapy, as heart rate reduction reduces exercise-induced ischemia by increasing diastolic perfusion time. However these are distinct actions and other anti-anginal agents (ranolazine, trimetazidine) can reduce exercise-induced ischemia without having any effect on diastolic perfusion time. ${ }^{2}$ During exercise, increase in left ventricular (LV) filling rate depends on the ability of the left ventricle to relax and $\beta$-blockers alter this relaxation process by their intrinsic negative inotropic properties. Studies with experimental animals demonstrated that ivabradine, unlike atenolol, reduced exercise-induced acceleration in heart rate without simultaneously exerting intrinsic depressant effects on of the rate of LV relaxation..$^{22}$ Further studies demonstrated 
Figure 2. (a) Inhibition of f-channels influences the pacemaker activity of sinoatrial myocytes; ${ }^{11,19}$ (b) selective inhibition of the If current reduces heart rate by changing the diastolic depolarisation slope which controls the frequency of the action potential. ${ }^{13,21,23}$

a)

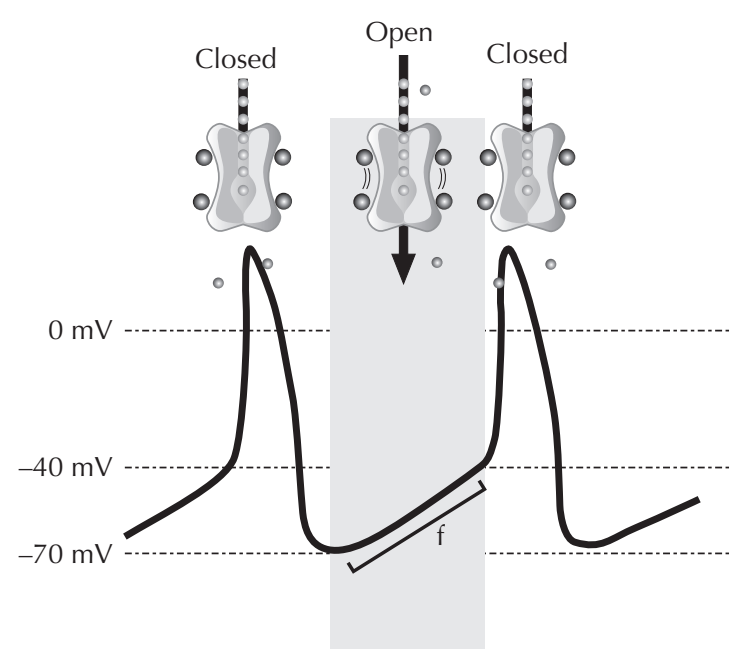

b)

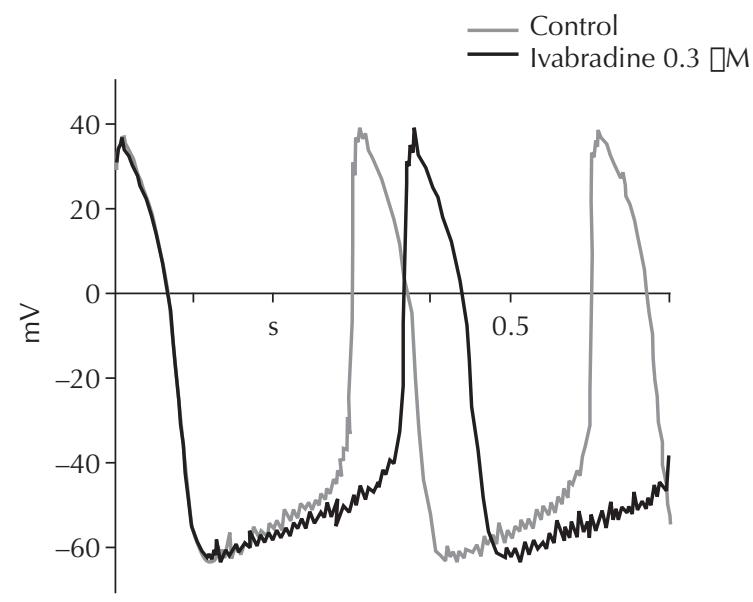

that heart rate and mycocardial contractility contribute equally to myocardial oxygen consumption during exercise in experimental animals and that negative inotropic effects of atenolol limited the increased diastolic filling time afforded by heart rate reduction. This was not seen with Ivabradine. ${ }^{25}$

Selective inhibition of $I_{\mathrm{f}}$ current by ivabradine was found to reduce heart rate both at rest and during exercise in experimental animals, without any inotropic effects or effect on left ventricular systolic function or coronary vasomotor activity $^{21,26-30}$ In a study with normal healthy volunteers, ivabradine reduced heart rate in a dose-dependent manner when administered intravenously and orally. ${ }^{31}$

In an experimental study in dogs the effect of the $\beta$-blocker atenolol and ivabradine on postsystolic wall thickening was compared. For a similar heart rate reduction at rest and during exercise, atenolol decreased the component of regional thickening devoted to ejection, whereas ivabradine preserved the part of thickening contributing to ejection. ${ }^{32,33}$

\section{Left ventricular function}

The effects of ivabradine and atenolol on left ventricular $(\mathrm{LV})$ function were compared on the ischaemic and stunned myocardium in experimental model of ischemia in dogs. Ivabradine improved regional contractility in the stunned myocardium whereas with atenolol it deteriorated further due to negative inotropism. These results may have important clinical implications in LV systolic dysfunctions. ${ }^{34,35}$

\section{Cardiac electrophysiology}

In a placebo controlled study comparing the effects of ivabradine, (administered orally as a single dose of $30 \mathrm{mg}$ ) and propanolol (40mg) on cardiac and systemic haemodynamics in nine healthy volunteers, there was no evidence of a negative inotropic effect which is a common and undesirable side effect with $\beta$-blockers. ${ }^{38}$

\section{Pharmacokinetics}

Ivabradine is rapidly and almost completely absorbed after oral administration with a peak plasma level reached in about one hour under 
fasting conditions $\left(\mathrm{t}_{\max } \approx 1 \mathrm{~h}\right)$ and an effective half life of 11 hours. The total clearance is around $400 \mathrm{~mL} / \mathrm{min}$ in patients and the absolute bioavailability of the film-coated tablets is around $40 \%$, due to first-pass effect in the gut and liver. Ivabradine is approximately $70 \%$ plasma protein bound. ${ }^{37}$

The N-desmethylated derivative of ivabradine, S-18982, has been identified as the main active metabolite in humans, with similar bradycardic activity and pharmacokinetic characteristics to ivabradine. S-18982 contributes about $40 \%$ of the activity of the parent compound. ${ }^{37}$ Pharmacokinetic/ pharmacodynamic population analysis using the NONMEM computer program suggested that $\mathrm{S}-18982$ is responsible for the initial bradycardic effect, whereas the parent compound is responsible for the duration of action. ${ }^{31,39}$ This was supported by a placebo controlled study in nine healthy volunteers, where ivabradine was found to decrease heart rate to the same extent as the reference $\beta$-blocker propanolol. The effects of ivabradine were found to be similar at two and five hours after drug administration, although plasma values of the drug were close to three times higher at two hours. These results indicated that pharmacological effects of ivabradine are related to sustained tissue binding possibly associated with the presence of an active metabolite. ${ }^{36,38}$

Ivabradine is extensively metabolised by the liver and the gut, being oxidised by the cytochrome CYP3A4 and it is also a very weak inhibitor of this cytochrome. Metabolic clearance accounts for $80 \%$ of ivabradine total clearance and the remaining 20\% is accounted for by renal clearance. CYP3A4 inhibitors and inducers may interact with ivabradine and influence its metabolism and pharmacokinetics to a clinically significant extent. ${ }^{37}$ The effects of CYP3A4 inhibitors omeprazole and lansoprazole on the pharmacokinetics of ivabradine and its active metabolite S18982 were assessed in normal healthy volunteers after a single oral dose of $10 \mathrm{mg}$ ivabradine, $40 \mathrm{mg}$ omeprazole or $60 \mathrm{mg}$ lansoprazole. No significant affect on the pharmacokinetics of ivabradine or its metabolite S18982 was found (Table 2). ${ }^{40}$ However, use with strong inhibitors of CYP3A4 (ketoconazole eryhthromycin, diltiazem or verapamil) is contraindicated as this may lead to a significant plasma exposure of ivabradine possibly resulting in risk of excessive bradycardia. ${ }^{37}$ The CYP3A4 inducer Hypericum perforatum was shown to reduce plasma concentration and availability of ivabradine and S18982 following co-administration with ivabradine in normal healthy volunteers. A shorter time to $\mathrm{G}_{\max }$ was observed and lower apparent terminal half-life values, consistent with an induction of ivabradine metabolism. ${ }^{41}$

\section{Special populations}

Ivabradine does not reliably slow heart rate during atrial fibrillation or other atrial tachycardia or in patients dependent on cardiac pacemakers. Therefore, it is only indicated for treatment in patients where heart rate is controlled by the sinus node. ${ }^{37}$

Heart failure must be appropriately controlled before considering ivabradine treatment. The use of ivabradine is contra-indicated in heart failure patients with NYHA functional classification IIIIV, due to a lack of data on clinical efficacy and safety. There is also insufficient data on clinical efficacy and safety in patients with asymptomatic left ventricular dysfunction or stroke patients. ${ }^{37}$

\section{Dosing}

Ivabradine (Procoralan) is available in tablet form at 5 and $7.5 \mathrm{mg}$. The usual recommended starting dose is $5 \mathrm{mg}$ twice-daily, in the morning and evenings during meals. After three to four weeks of treatment, the dose may be increased to $7.5 \mathrm{mg}$ twice-daily depending on the 
Table 2. Pharmacokinetic parametes of ivabradine after single oral administration of ivabradine $10 \mathrm{mg}$ alone or coadministered with $40 \mathrm{mg}$ omeprazole or $60 \mathrm{mg}$ lansoprazole. ${ }^{40}$

\begin{tabular}{|c|c|c|c|c|c|}
\hline $\begin{array}{l}\text { Ivabradine } \\
\text { pharmacokinetic } \\
\text { parameters }\end{array}$ & $\begin{array}{c}\text { Ivabradine } \\
(\mathrm{n}=12)\end{array}$ & $\begin{array}{c}\text { Ivabradine+ } \\
\text { omeprazole } \\
(I+O)(n=12)\end{array}$ & $\begin{array}{c}\text { Ivabradine+ } \\
\text { lansoprazole } \\
(\mathrm{I}+\mathrm{L})) \mathrm{n}=12)\end{array}$ & $\begin{array}{c}\text { Geometric } \\
\text { mean ratio } \\
(\mathrm{I}+\mathrm{O})(\mathrm{I})[95 \% \mathrm{CI}]\end{array}$ & $\begin{array}{c}\text { Geometric } \\
\text { mean ratio } \\
(\mathrm{I}+\mathrm{L})(\mathrm{I})[95 \% \mathrm{CI}]\end{array}$ \\
\hline \multicolumn{6}{|l|}{$\mathrm{t}_{\max } \cdot \mathrm{h}$} \\
\hline Mean \pm SD & $0.96 \pm 0.41$ & $1.02 \pm 0.61$ & $1.65 \pm 1.20$ & - & - \\
\hline Median & 0.75 & 0.75 & 1.25 & - & - \\
\hline Range & $0.50-2.00$ & $0.50-2.00$ & $0.50-4.00$ & - & - \\
\hline$p$ value & (Wilcoxon) & 0.73 & 0.05 & - & - \\
\hline \multicolumn{6}{|l|}{$\mathrm{C}_{\max } \cdot \mathrm{ng} / \mathrm{mL}$} \\
\hline Mean \pm SD & $45.0 \pm 36.6$ & $42.7 \pm 27.6$ & $41.3 \pm 29.4$ & $0.99[0.73-1.35]$ & $0.96[0.75-1.23]$ \\
\hline Gemetric mean & 36.0 & 35.9 & 34.4 & - & - \\
\hline Median & 31.0 & 31.5 & 33.2 & - & - \\
\hline Range & $15.0-141$ & $11.1-110$ & $14.8-115$ & - & - \\
\hline$p$ value & & 0.98 & 0.70 & 0.98 & 0.70 \\
\hline \multicolumn{6}{|l|}{$\mathrm{AUC}, \mathrm{ng} \bullet \mathrm{h} / \mathrm{mL}$} \\
\hline M ean \pm SD & $128 \pm 87$ & $126 \pm 63[0.85-1.22]$ & $1.23 \pm 50[0.86-1.23)$ & 1.02 & 1.03 \\
\hline Gemetric mean & 111.8 & 113.9 & 15.0 & - & - \\
\hline Median & 88.4 & 96.4 & 98.8 & - & - \\
\hline Range & $69.6-371$ & $67.7-255$ & $66.0-239$ & - & - \\
\hline$p$ value & & 0.82 & 0.73 & 0.82 & .73 \\
\hline \multicolumn{6}{|l|}{$\mathrm{t} 1 / 2 \cdot \mathrm{h}$} \\
\hline Mean \pm SD & $1.92 \pm 0.39$ & $2.07 \pm 0.53$ & $1.98 \pm 0.42$ & - & - \\
\hline Median & 1.83 & 1.83 & 1.96 & - & - \\
\hline Range & $1.28-2.63$ & $1.29-2.87$ & $1.27-2.59$ & - & - \\
\hline \multicolumn{6}{|l|}{$\mathrm{Cl} / \mathrm{F}, \mathrm{mL} / \mathrm{min}$} \\
\hline Mean & 1633 & 1600 & 1500 & - & - \\
\hline
\end{tabular}

$\mathrm{Cl}$, confidence interval, I + O, ivabradine + omeprazole, I + L, ivabradine + lansoprazole, I, ivabradine.

therapeutic response. If, during treatment, heart rate decreases persistently below 50 beats per minute (bpm) at rest or the patient experiences symptoms related to bradycardia such as dizziness, fatigue or hypotension, the dose must be titrated downward including the possible dose of $2.5 \mathrm{mg}$ twice-daily (one half $5 \mathrm{mg}$ tablet twicedaily). Treatment must be discontinued if heart rate below $50 \mathrm{bpm}$ or symptoms of bradycardia persist. ${ }^{37,56}$ Ivabradine is not recommended for children or adolescents as its efficacy and safety have not been studied in these populations

\section{Coadministration with other drugs}

Concomitant use of ivabradine with heart rate reducing calcium channel blockers such as verapamil or diltiazem is not recommended. Ivabradine should also not be used in combination with QT prolonging agents. There is no evidence for contraindication in taking ivabradine in combination with other cardiovascular drugs, including anti-platelet agents (aspirin) statins, angiotensin-converting enzymes. ${ }^{37}$

\section{CLINICAL EFFICACY}

The clinical efficacy of ivabradine as antianginal and antiischemic treatment for patients with stable angina has been investigated in several clinical trials as monotherapy and in combination with other antianginal drugs. In each of these studies exercise tolerance testing was used to assess clinical efficacy. The primary efficacy criteria were time to limiting angina and time to angina onset, as a measure of angina, and time to 1-mm ST-segment depression as a measure of ischemia. Ivabradine has also been compared 
to $\beta$-blockers and calcium channel-blockers in terms of efficacy and tolerability.

\section{Monotherapy - Placebo controlled trials}

The therapeutic effects of ivabradine were first investigated in a randomised, placebocontrolled trial of 360 patients with chronic stable angina who received 2.5, 5 or $10 \mathrm{mg}$ ivabradine twice- daily for two weeks. This was followed by an extension period for 173 patients who received $10 \mathrm{mg}$ ivabradine for a further two to three months. ${ }^{42,43}$ After two weeks of treatment, heart rate at rest and during exercise was significantly lowered in a dose-dependent manner at both peak and trough drug activity (Table 3 ). In addition, exercise tolerance was significantly improved and time to angina onset was increased at all doses compared to placebo, with a mean change of time in seconds of 24.7, 37.6, 38.8, and 69.4 at trough drug activity with placebo, ivabradine $2.5,5,10 \mathrm{mg}$ respectively (Table 3). ${ }^{42}$ This effect persisted throughout the extension period and there was no evidence of rebound phenomena or tolerance in any treatment group. ${ }^{42}$

\section{Comparison with the beta blocker atenolol}

The INITIATIVE study (International Trial on the AnTi-anginal effects of IVabradinE compared to atenolol) compared the effects of ivabradine and atenolol on exercise capacity in patients with chronic stable angina who were known to tolerate atenolol. In this placebocontrolled double-blind trial, 939 patients were randomised to receive $5 \mathrm{mg}$ ivabradine for four weeks and then 7.5 or $10 \mathrm{mg}$ ivabradine twicedaily for 12 weeks; or $50 \mathrm{mg}$ atenolol for four weeks then $100 \mathrm{mg}$ atenolol once-daily for 12 weeks. Mean increase in total exercise duration at trough drug activity was 86.8 and $91.7 \mathrm{~s}$, with ivabradine 7.5 and $10 \mathrm{mg}$ respectively, and 78.8 s with $100 \mathrm{mg}$ atenolol (Table 4$).{ }^{44}$ Time to angina onset and time to limiting angina were increased in all treatment groups and noninferiority of ivabradine compared to atenolol

Table 3. Changes in exercise tolerance tests in different ivabradine treatment groups compared with placebo. ${ }^{42}$

\begin{tabular}{|c|c|c|c|c|c|}
\hline Parameter & $\begin{array}{l}\text { Placebo } \\
(n=68)\end{array}$ & $\begin{array}{c}\text { Ivabradine } \\
2.5 \text { mg bid } \\
(n=64)\end{array}$ & $\begin{array}{c}\text { Ivabradine } \\
5 \text { mg bid } \\
(n=59)\end{array}$ & $\begin{array}{c}\text { Ivabradine } \\
10 \text { mg bid } \\
(n=66)\end{array}$ & $\begin{array}{c}\text { Between- } \\
\text { group } \\
p\end{array}$ \\
\hline \multicolumn{6}{|c|}{ Time to $1 \mathrm{~mm}$ ST-depression, $\mathrm{s}$} \\
\hline Day 0 & $369.1 \pm 119.0$ & $343.7 \pm 120.7$ & $364.1 \pm 119.3$ & $370.2 \pm 120.8$ & \\
\hline Day 14 & $378.0 \pm 124.2$ & $375.7 \pm 121.2$ & $408.2 \pm 122.8$ & $416.4 \pm 155.7$ & \\
\hline Day 14-Day 0 & $9.0 \pm 63.6$ & $32.0 \pm 74.3$ & $44.1 \pm 80.1^{*}$ & $46.2 \pm 78.2^{*}$ & 0.016 \\
\hline \multicolumn{6}{|c|}{ Time to limiting angina, $s$} \\
\hline Day 0 & $417.8 \pm 115.6$ & $402.5 \pm 121.0$ & $432.8 \pm 124.0$ & $430.5 \pm 125.4$ & \\
\hline Day 14 & $430.5 \pm 119.0$ & $425.0 \pm 116.4$ & $460.0 \pm 115.1$ & $471.3 \pm 148.4$ & \\
\hline Day 14-Day 0 & $12.7 \pm 51.3$ & $22.5 \pm 55.4$ & $27.2 \pm 56.8$ & $40.8 \pm 69.3^{*}$ & 0.049 \\
\hline \multicolumn{6}{|c|}{ Time to angina, onset, $\mathrm{s}$} \\
\hline Day 0 & $352.8 \pm 98.2$ & $330.5 \pm 106.4$ & $355.6 \pm 110.9$ & $351.5 \pm 123.1$ & \\
\hline Day 14 & $377.5 \pm 116.3$ & $366.1 \pm 112.5$ & $394.4 \pm 132.3$ & $420.8 \pm 148.5$ & \\
\hline Day 14-Day 0 & $24.7 \pm 64.2$ & $37.6 \pm 57.7$ & $38.8 \pm 81.7$ & $69.4 \pm 74.8^{*}$ & 0.003 \\
\hline \multicolumn{6}{|c|}{ RPP at peak of exercise, bpm/mmHg } \\
\hline Day 0 & $23057 \pm 5498$ & $23924 \pm 4885$ & $24772 \pm 5757$ & $24163 \pm 4623$ & \\
\hline Day 14 & $23323 \pm 5458$ & $23187 \pm 5062$ & $23630 \pm 5253$ & $22640-4540$ & \\
\hline Day 14-Day 0 & $266 \pm 3074$ & $-737 \pm 2960$ & $-1142 \pm 3354 *$ & $-1543 \pm 3526 *$ & 0.011 \\
\hline \multicolumn{6}{|c|}{ Total work performed, w/min } \\
\hline Day 0 & $501.7 \pm 246.2$ & $473.9 \pm 240.6$ & $538.0 \pm 269.6$ & $534.0 \pm 278.8$ & \\
\hline Day 14 & $529.1 \pm 256.8$ & $515.6 \pm 241.8$ & $588.3 \pm 260.2$ & $633.1 \pm 373.5$ & \\
\hline Day 14-Day 0 & $27.4 \pm 104.7$ & $41.7 \pm 112.7$ & $50.3 \pm 122.4$ & $99.1 \pm 192.0 *$ & 0.019 \\
\hline
\end{tabular}


Figure 3. Changes in heart rate at rest and at peak exercise in different ivabradine treatment groups compared with placebo. ${ }^{42}$

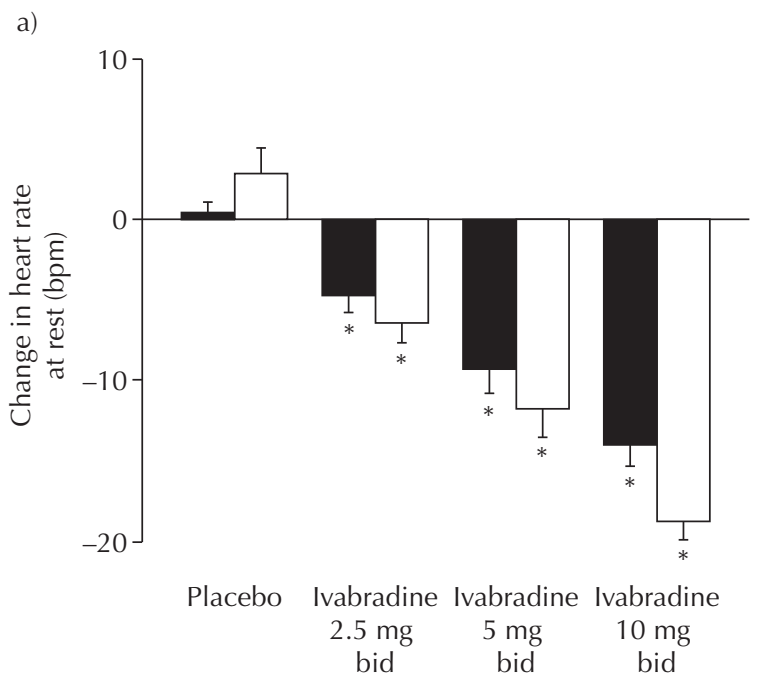

was shown at all doses for all criteria. The mean differences between treatment groups for total exercise at trough drug activity were

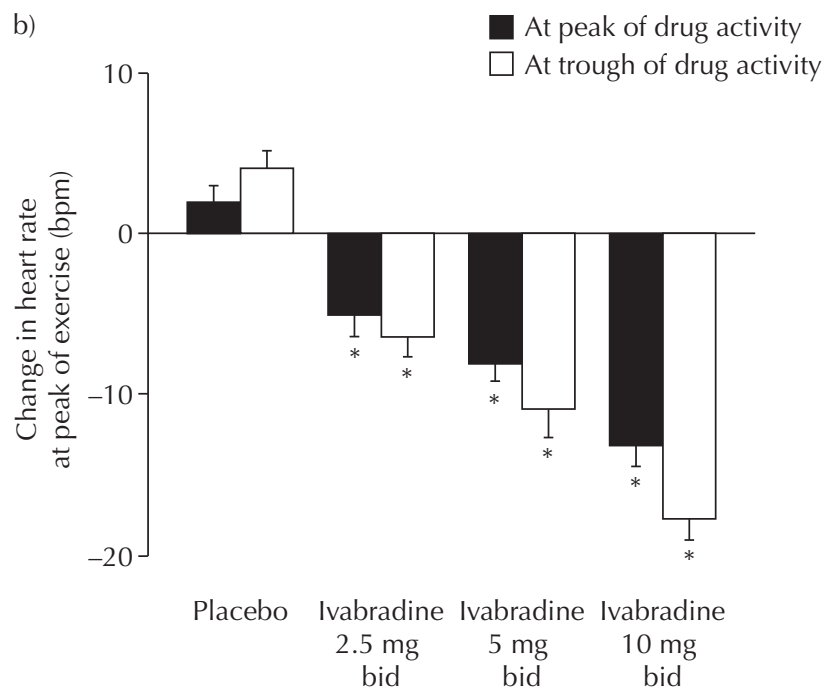

10.3 and $15.7 \mathrm{~s}$ in favour of ivabradine 7.5 and $10 \mathrm{mg}$ respectively compared to atenolol $100 \mathrm{mg}\left(p<0.001\right.$ for inferiority) (Figure 4). ${ }^{44}$

Table 4. Changes in exercise tests at trough drug activity in different ivabradine treatment groups compared with atenolol. ${ }^{44}$

\begin{tabular}{|c|c|c|c|}
\hline & $\begin{array}{l}\text { Ivabradine } 7.5 \mathrm{mg} \text { bid } \\
\qquad(\mathrm{n}=300)\end{array}$ & $\begin{array}{l}\text { Ivabradine } 10 \mathrm{mg} \text { bid } \\
\qquad(\mathrm{n}=298)\end{array}$ & $\begin{array}{l}\text { Atenolol } 100 \mathrm{mg} \text { od } \\
(\mathrm{n}=286)\end{array}$ \\
\hline \multicolumn{4}{|l|}{ Total exercise duration (s) } \\
\hline Baseline & $594.9 \pm 141.6$ & $590.8 \pm 142.9$ & $578.2 \pm 144.2$ \\
\hline Change & $86.8 \pm 129.0$ & $91.7 \pm 118.8$ & $78.8 \pm 133.4$ \\
\hline Difference $^{a}(\mathrm{SE})$ & $10.3(9.4)$ & $15.7(9.5)$ & \\
\hline $91 \% \mathrm{Cls}$ & {$[-8.3 ; 28 / 8]$} & {$[-2.9 ; 34.3]$} & \\
\hline$p$ value, non-inferiority & $p<0.001$ & $p<0.001$ & \\
\hline \multicolumn{4}{|l|}{ Time to limiting angina (s) } \\
\hline Baseline & $587.0 \pm 138.0$ & $583.5 \pm 139.6$ & $568.1 \pm 139.8$ \\
\hline Change & $91.8 \pm 131.1$ & $96.9 \pm 121.2$ & $85.4 \pm 133.7$ \\
\hline Difference ${ }^{a}(S E)$ & $9.3(9.7)$ & $15.1(9.7)$ & \\
\hline $91 \% \mathrm{Cls}$ & {$[-9.6 ; 28.3]$} & {$[-3.9 ; 34.0]$} & \\
\hline$p$ value, non-inferiority & $p<0.001$ & $p<0.001$ & \\
\hline \multicolumn{4}{|l|}{ Time to angina onset (s) } \\
\hline Baseline & $468.0 \pm 147.1$ & $477.0 \pm 147.8$ & $457.4 \pm 145.0$ \\
\hline Change & $145.2 \pm 153.4$ & $139.6 \pm 140.6$ & $135.2 \pm 154.7$ \\
\hline Difference ${ }^{a}(\mathrm{SE})$ & $12.1(11.5)$ & $10.1(11.6)$ & \\
\hline $91 \% \mathrm{Cls}$ & {$[-10,5 ; 34.7]$} & {$[-12.5 ; 32.8]$} & \\
\hline$p$ value, non-inferiority & $p<0.001$ & $p<0.001$ & \\
\hline \multicolumn{4}{|c|}{ Time to $1 \mathrm{~mm}$ ST depression (s) } \\
\hline Baseline & $521.7 \pm 164.3$ & $528.6 \pm 161.8$ & $510.7 \pm 156.0$ \\
\hline Change & $98.0 \pm 153.7$ & $86.9 \pm 128.2$ & $95.6 \pm 147.5$ \\
\hline Difference ${ }^{a}(\mathrm{SE})$ & $4.3(10.7)$ & $-3.3(10.8)$ & \\
\hline $91 \% \mathrm{Cls}$ & {$[-16.8 ; 25.3]$} & {$[-24.4 ; 17.8]$} & \\
\hline$p$ value, non-inferiority & $p<0.001$ & $p=0.002$ & \\
\hline
\end{tabular}


Figure 4. Comparison of the effects of ivabradine and atenolol on total exercise duration at trough drug activity. ${ }^{44}$

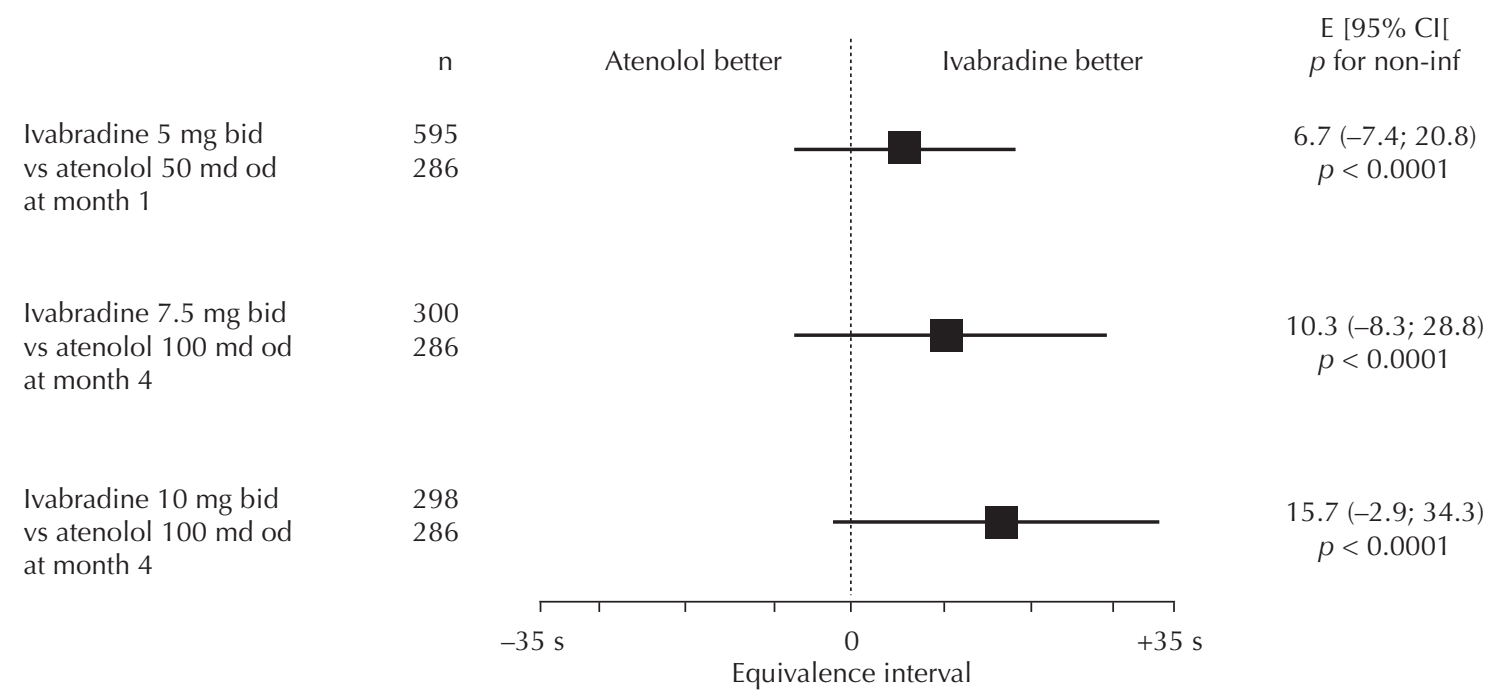

Both atenolol and ivabradine decreased angina attacks by $66 \%{ }^{42}$

A subset 232 patients from the INITIATIVE study population aged 65 years or older, were analysed with respect to the antianginal and antiischemic effects of ivabradine compared to atenolol. In this group, total exercise duration increased by a mean of $88.7 \mathrm{~s}$ with $7.5 \mathrm{mg}$ ivabradine twice-daily and by $65.6 \mathrm{~s}$ with $100 \mathrm{mg}$ atenolol once-daily, confirming non-inferiority of ivabradine antianginal efficacy in this subset. Time to 1-mm ST-segment depression increased by a mean of $101.9 \mathrm{~s}$ and $81.7 \mathrm{~s}$ with $7.5 \mathrm{mg}$ ivabradine and $100 \mathrm{mg}$ atenolol, respectively, which was within equivalence levels. These results confirmed that good clinical efficacy and tolerability is maintained in the elderly and this may have important clinical implications since the prevalence of angina is increasing in the over 65 age group. ${ }^{45}$

\section{Comparison with the calcium channel blocker amlodipine}

The antianginal efficacy of ivabradine was compared with the long-acting calcium channel blocker amlodipine, which is recommended as second-line therapy in angina although may be used as first-line therapy in patients who are intolerant of $\beta$-blockers or rate-limiting calcium channel-blockers (verapamil and diltiazem). ${ }^{1}$ The study included 1195 patients with at least a three month history of chronic stable effortinduced angina. Patients were randomised to receive $7.5 \mathrm{mg}$ or $10 \mathrm{mg}$ ivabradine twice-daily or $10 \mathrm{mg}$ amlodipine once-daily. After three months treatment ivabradine had comparable efficacy to amlodipine in improving total exercise tolerance with a mean improvement in of 27.6, 21.7 and $31.2 \mathrm{~s}$ with 7.5 or $10 \mathrm{mg}$ ivabradine and $10 \mathrm{mg}$ amlodipine respectively (Table 5 and Figure 5). ${ }^{46,47}$ Antianginal and antiischemic efficacy was demonstrated by reduced time to angina onset and time to limiting angina in all treatment groups; also frequency of angina attack and use of short-acting nitrates was reduced. Heart rate decreased significantly by an average of 11-13 beats/min at rest and 12-15 beats/min at peak exercise with ivabradine but not amlodipine $(p<0.001)$. This effect was seen at rest and at peak of exercise and was evident within the first month of treatment remaining stable throughout the trial period. Ivabradine had superior efficacy 
Table 5. Exercise tolerance test parameters at baseline and three months measured at trough drug activity with ivabradine and amlodipine. ${ }^{47}$

\begin{tabular}{|c|c|c|c|c|c|c|c|}
\hline Variable & $\begin{array}{c}\text { Amlodipine } \\
10 \text { mg od } \\
(n=398)\end{array}$ & $\begin{array}{c}\text { Ivabradine } \\
7.5 \text { mg bid } \\
(n=381)\end{array}$ & $\begin{array}{c}\text { Difference vs } \\
\text { amlodipine } \\
\text { E }^{\mathrm{a}}(\mathrm{SE}) \\
{[95 \%, \mathrm{CI}]}\end{array}$ & $\begin{array}{c}p \text { value for } \\
\text { non-inferiority }\end{array}$ & $\begin{array}{c}\text { Ivabradine } \\
10 \text { mg bid } \\
(n=376)\end{array}$ & $\begin{array}{c}\text { Difference vs } \\
\text { amlodipine } \\
\text { Ea }^{a}(\mathrm{SE}) \\
{[95 \%, \mathrm{Cl}]}\end{array}$ & $\begin{array}{c}\text { p value for } \\
\text { non-inferiority }\end{array}$ \\
\hline \multicolumn{8}{|c|}{ Total exercise duration (sec) } \\
\hline Baseline & $400.1 \pm 131.9$ & $414.4 \pm 133.0$ & & & $423.6 \pm 142.6$ & & \\
\hline 3 months & $431.2 \pm 140.9$ & $442.0 \pm 154.5$ & & & $445.3 \pm 155.5$ & & \\
\hline Change at 3 months & $31.2 \pm 92.9$ & $27.6 \pm 91.7$ & $\begin{array}{c}-1.8(6.6) \\
{[-14.6,11.1]}\end{array}$ & $<0.001$ & $21.7 \pm 94.5$ & $\begin{array}{c}-6.6(6.6) \\
{[-19.5,6.3]}\end{array}$ & $<0.001$ \\
\hline \multicolumn{8}{|c|}{ Time to angina onset (sec) } \\
\hline Baseline & $313.0 \pm 121.8$ & $325.2 \pm 119.9$ & & & $331.4 \pm 125.7$ & & \\
\hline 3 months & $379.5 \pm 143.2$ & $389.9 \pm 156.4$ & & & $391.1 \pm 157.2$ & & \\
\hline Change at 3 months & $66.6 \pm 99.1$ & $64.7 \pm 104.9$ & $\begin{array}{c}-0.6(7.4) \\
{[-15.2,14.0]}\end{array}$ & $<0.001$ & $59.7 \pm 110.8$ & $\begin{array}{c}-4.6(7.5) \\
{[-19.3,10.1]}\end{array}$ & $<0.001$ \\
\hline \multicolumn{8}{|c|}{ Time to $1 \mathrm{~mm}$ St-segment depression (sec) } \\
\hline Baseline & $347.4 \pm 123.0$ & $355.0 \pm 122.4$ & & & $366.9 \pm 130.9$ & & \\
\hline 3 months & $387.1 \pm 138.4$ & $400.0 \pm 152.2$ & & & $401.5 \pm 149.6$ & & \\
\hline Change at 3 months & $39.7 \pm 103.2$ & $44.9 \pm 98.6$ & $\begin{array}{c}6.5(7.2) \\
{[-7.6,20.6]}\end{array}$ & $<0.001$ & $34.7 \pm 104.5$ & $\begin{array}{c}-1.8(8.2) \\
{[-16.0,12.3]}\end{array}$ & $<0.001$ \\
\hline
\end{tabular}

${ }^{\mathrm{a}} \mathrm{E}(\mathrm{SE})$ and $\mathrm{Cl}$ of the difference between ivabradine effect and amlodipine effect, based on a covariance analysis adjusted on baseline and country factors. O ther values are mean \pm standard deviation.

bFor a non-inferiority margin of -30 seconds.

bid, twice daily; $\mathrm{Cl}$, confidence interval; $\mathrm{E}(\mathrm{SE})$, estimate (standard error); od, once daily.

Figure 5. Comparison of the effects of ivabradine and amlodipine on total exercise duration at trough drug activity. ${ }^{46}$

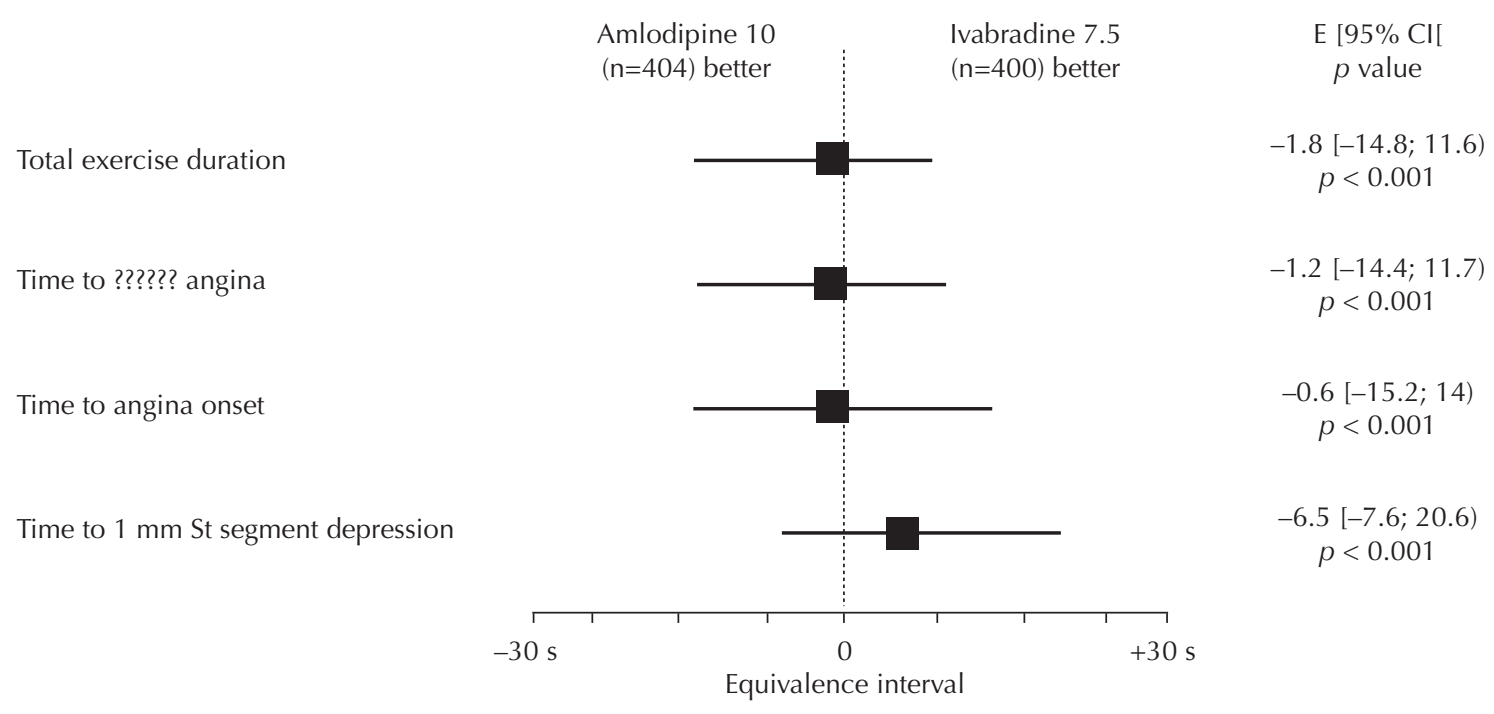

to amlodipine in reducing rate-pressure product (heart rate times blood pressure) as a marker of myocardial oxygen consumption $(p<0.001$ ivabradine vs amlodipine) (Table 6). ${ }^{47}$ After three months there was a $60 \%$ reduction in frequency of angina attacks in all treatment groups with mean decreases of 3.0, 3.2 and 3.0 attacks/week for ivabradine 7.5 and $10 \mathrm{mg}$ and amlodipine $10 \mathrm{mg}$ respectively. ${ }^{47}$ 
Table 6. Changes in heart rate and rate-pressure product at three months measured at trough drug activity with ivabradine and amlodipine. ${ }^{47}$

\begin{tabular}{|c|c|c|c|c|c|}
\hline Variable & $\begin{array}{l}\text { Amlodipine } \\
10 \text { mg od } \\
(n=398)\end{array}$ & $\begin{array}{c}\text { Ivabradine } \\
7.5 \text { mg bid } \\
(\mathrm{n}=381)\end{array}$ & $\begin{array}{c}\text { Difference vs } \\
\text { amlodipine } \mathrm{E}(\mathrm{SE})^{\mathrm{a}} \\
{[91 \% \mathrm{CI}]}\end{array}$ & $\begin{array}{l}\text { Ivabradine } \\
10 \text { mg bid } \\
(n=376)\end{array}$ & $\begin{array}{c}\text { Difference vs } \\
\text { amlodipine E (SE) } \\
{[95 \% \mathrm{CI}]}\end{array}$ \\
\hline \multicolumn{6}{|l|}{ Heart rate at rest } \\
\hline Baseline & $78.8 \pm 13.4$ & $78.6 \pm 13.0$ & & $78.1 \pm 14.1$ & \\
\hline 3 months & $78.6 \pm 13.2$ & $67.4 \pm 11.8$ & & $65.1 \pm 12.8$ & \\
\hline Change at 3 months & $-0.2 \pm 12.2$ & $-11.2 \pm 12.5$ & $-11.1(0.8)$ & $-13.1 \pm 13.5$ & $-13.1(0.8)$ \\
\hline$[95 \% \mathrm{Cl}]^{b}$ & {$[-1.5,1.0]$} & {$[-12.5,-10.0]$} & {$[-12.6,-9.6]$} & {$[-14.4,-11.8]$} & {$[-11.7,-11.6]$} \\
\hline$p$ value ${ }^{c}$ vs baseline & $p=0.720$ & $p<0.001$ & & $p<0.001$ & \\
\hline$p$ value ${ }^{d}$ vs amlodipine & & $p<0.001$ & & $p<0.001$ & \\
\hline \multicolumn{6}{|c|}{ Heart rate at peak of exercise } \\
\hline Baseline & $131.0 \pm 18.4$ & $132.1 \pm 18.9$ & & $132.1 \pm 18.8$ & \\
\hline 3 months & $130.8 \pm 17.5$ & $119.7 \pm 7.1$ & & $117.0 \pm 17.6$ & \\
\hline Change at 3 months & $-0.2 \pm 12.8$ & $-12.4 \pm 15.3$ & $-11.8(0.9)$ & $-15.1 \pm 14.4$ & $-145(9.0)$ \\
\hline$[95 \% \mathrm{Cl}]^{b}$ & {$[-1.6,1.3]$} & {$[-13.9,-11.0]$} & {$[-13.6,-10.1]$} & {$[-16.5,-13.4]$} & {$[-16.3,-12.7]$} \\
\hline$p$ value ${ }^{c}$ vs baseline & $p=0.829$ & $p<0.001$ & & $p<0.001$ & \\
\hline$p$ value ${ }^{d}$ vs amlodipine & & $p<0.001$ & & $p<0.001$ & \\
\hline \multicolumn{6}{|c|}{ Rate-pressure product at rest } \\
\hline Baseline & $10.377 \pm 2284$ & $10437 \pm 2282$ & & $10426 \pm 2418$ & \\
\hline 3 months & $9827 \pm 2112$ & $8990 \pm 2019$ & & $8764 \pm 2064$ & \\
\hline Change at 3 months & $-550 \pm 1978$ & $-1447 \pm 2071$ & $-865(122)$ & $-1664 \pm 2238$ & $-1078(12.3)$ \\
\hline$[95 \% \mathrm{Cl}]^{b}$ & {$[756,-344]$} & {$[-1658,-1236]$} & {$[-1105,-625]$} & {$[1876,-1452]$} & {$[-1319,-838]$} \\
\hline$p$ value ${ }^{c}$ vs baseline & $p<0.001$ & $p<0.001$ & & $p<0.001$ & \\
\hline$p$ value $^{d}$ vs amlodipine & & $p<0.001$ & & $p<0.001$ & \\
\hline \multicolumn{6}{|c|}{ Rate-pressure product at peak of exercise } \\
\hline Baseline & $23403 \pm 5084$ & $23850 \pm 5203$ & & $24158 \pm 5240$ & \\
\hline 3 months & $23012 \pm 4955$ & $21295 \pm 5002$ & & $21854 \pm 5012$ & \\
\hline Change at 3 months & $-471 \pm 4042$ & $-1926 \pm 3848$ & $-1325(258)$ & $-2304 \pm 4077$ & $-1588(250)$ \\
\hline$[95 \% \mathrm{Cl}]^{\mathrm{b}}$ & {$[-855,-77]$} & {$[-2328,1526]$} & {$[-1831,-819]$} & {$[-2709,-1900]$} & {$[-2095,-1080]$} \\
\hline$p$ value ${ }^{c}$ vs baseline & $p=0.019$ & $p<0.001$ & & $p<0.001$ & \\
\hline$p$ value ${ }^{d}$ vs amlodipine & & $p<0.001$ & & $p<0.001$ & \\
\hline
\end{tabular}

${ }^{a} \mathrm{E}(\mathrm{SE})$ and $\mathrm{Cl}$ of the difference between ivabradine effect and amlodipine effect, based on a covariance analysis adjusted on baseline and country factors. O ther values are mean \pm standard deviation.

${ }^{b} \mathrm{Cl}$ of the change within treatment group based on an analysis ov variance without adjustment.

'Student's t-test based on the overall general linear model (least-squares norm).

'Student's t-test based on the overall general linear model (least squares norm) with baseline as a covariate and country as a random factor.

bid, twice daily; $\mathrm{Cl}$, confidence interval; $\mathrm{E}(\mathrm{SE})$, estimate (standard error); od, once daily.

\section{Long term efficacy with combination therapy}

The first studies with ivabradine clearly demonstrated therapeutic efficacy within a few weeks of treatment ${ }^{42}$ and non-inferiority compared to other antianginal therapies with effects lasting for up to four months. ${ }^{44,47}$ The duration of ivabradine efficacy over a 12 month period was investigated in 386 patients randomised to receive 5 or $7.5 \mathrm{mg}$ ivabradine twice-daily for 12 months, while continuing their existing therapy. These concomitant medications included antithrombotic agents, lipid-lowering agents, long-acting nitrates and dihydropyridine calcium antagonists. Non-dihydropyridine calcium antagonists were not permitted as they can increase ivabradine exposure through inhibition of CYP3A4. $\beta$-blockers were not permitted as concomitant medication. ${ }^{48,49}$ Heart rate was measured at 1, 3, 6, 9 and 12 months and was significantly reduced by a mean of 9.7 and 12.3 beats per minute from baseline with 5 and $7.5 \mathrm{mg}$ ivabradine respectively. Maximal effect was seen by 4 weeks and remained stable for the duration of the study, with no indication 
Figure 6. Persistent heart rate reduction over 12 months of ivabradine treatment. ${ }^{49}$

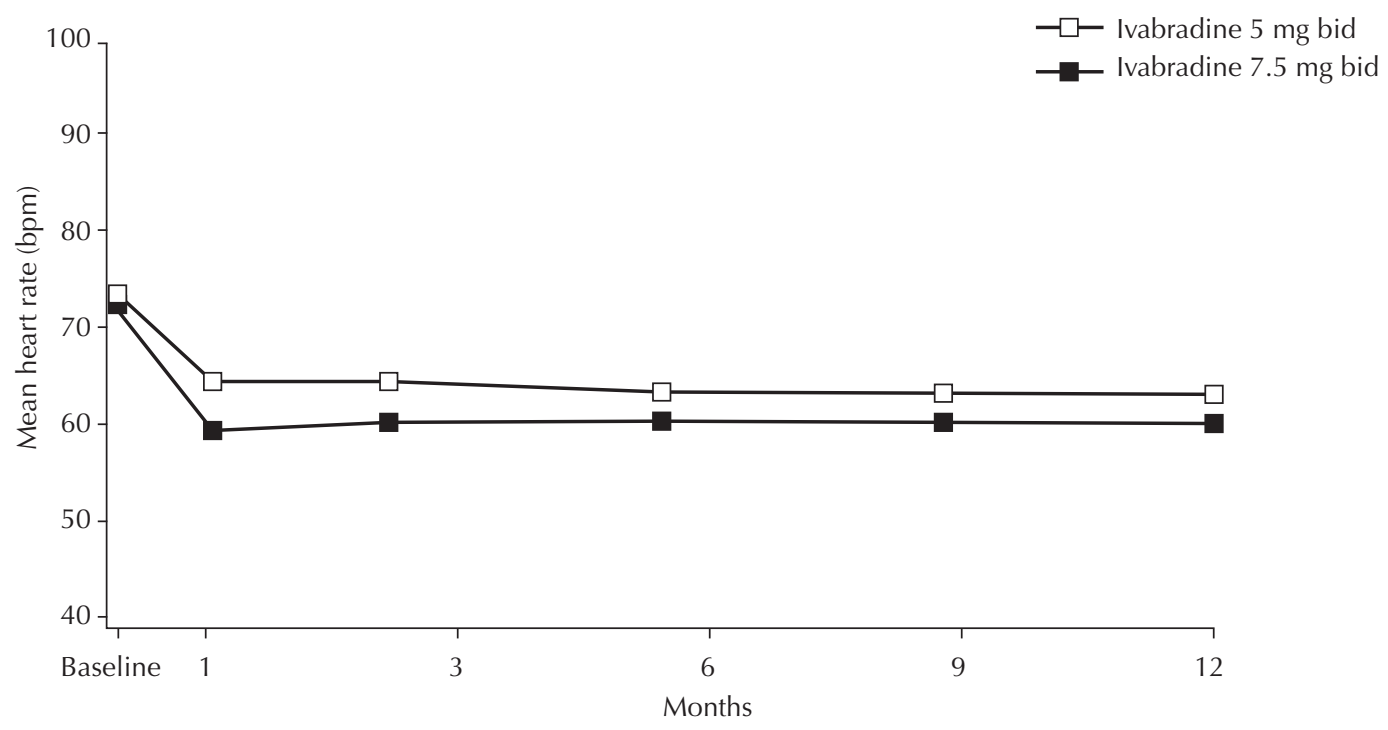

Table 7. Reduction in number of angina attacks in ivabradine treatment groups with and without concomitant antianginal therapy. ${ }^{49}$

\begin{tabular}{|c|c|c|c|c|}
\hline \multirow{3}{*}{$\begin{array}{l}\text { Angina attacks } \\
(\text { mean } \pm S D)\end{array}$} & \multicolumn{4}{|c|}{ Ivabradine } \\
\hline & \multicolumn{2}{|c|}{ All patients } & \multicolumn{2}{|c|}{$\begin{array}{l}\text { Patients receiving ivabradine on top of } \\
\text { concomitant antianginal therapy }\end{array}$} \\
\hline & $5 \mathrm{mg}$ bid $(\mathrm{n}=191)^{\mathrm{a}}$ & $7.5 \mathrm{mg}$ bid $(\mathrm{n}=179)^{\mathrm{a}}$ & $5 \mathrm{mg}$ bid $(\mathrm{n}=136)^{\mathrm{a}}$ & $7.5 \mathrm{mg}$ bid $(\mathrm{n}=123)^{\mathrm{a}}$ \\
\hline Baseline (month 0) & $2.9 \pm 5.3$ & $2.3 \pm 3.9$ & $3.1 \pm 5.5$ & $2.1 \pm 3.4$ \\
\hline 12 months & $1.0 \pm 2.7$ & $1.1 \pm 3.8$ & $0.8 \pm 19$ & $1.2 \pm 3.5$ \\
\hline Change & $-1.9 \pm 4.8(-2.6,-1.3)$ & $-1.2 \pm 4.1(-1.9,-0.5)$ & $-2.3 \pm 5.2(-3.1,-1.6)$ & $-0.9 \pm 3.4(-1.7,-0.1)$ \\
\hline$p$ value vs baseline ${ }^{b}$ & $p<0.001$ & $p<0.001$ & $p<0.001$ & $p=0.022$ \\
\hline
\end{tabular}

a N umber of patients with assessable diary at baseline and month 12 .

${ }^{\mathrm{b}} p$ value $=$ parametric approach without adjustment.

of pharmacological tolerance developing (Figure 6). ${ }^{47}$ The mean number of angina attacks was reduced by $50 \%$ in both treatment groups $(p<0.001)$, including patients taking concomitant antianginal therapy (Table 7). Short-acting nitrate consumption was also reduced by $50 \%$ in both treatment groups. ${ }^{48,49}$

\section{Efficacy beyond angina}

A long-term outcome study was initiated in 2005 to determine whether pure heart rate reduction extends clinical benefit beyond improving symptoms in patients with stable angina. The BEAUTI $_{\mathrm{F}} \mathrm{UL}$ (morBidity-mortality EvAiUaTion of the $I_{f}$ inhibitor ivabradine in patients with coronary disease and left ventricuLar dysfunction) study recruited 10,000 patients into a threeyear placebo controlled trial to determine the prognostic benefits of ivabradine for patients with $\mathrm{CAD}$ and left ventricular dysfunction (LVD). The end point of the study will be the clinical outcomes of myocardial infarction and mortality. ${ }^{50,51}$

\section{SAFETY AND TOLERABILITY}

Most medications currently available for treating angina have unpleasant and sometimes severe side effects, and these are often compounded 
by the need for combination therapy to control symptoms in some patients. Poor compliance due to unacceptable side effects has been a major cause for poor symptom control in many angina patients. ${ }^{2}$ Ivabradine has been demonstrated to have a very good safety profile in its clinical development programme in which 3500 patients overall were treated with ivabradine and 1200 of these were treated for more than one year. ${ }^{15}$ Ivabradine was found to be well tolerated and safe due to its specific and selective mode of action.

In all studies of ivabradine clinical efficacy, visual symptoms were the most frequently reported adverse event. Although ivabradine is selective for the f-channels it can also react with $\mathrm{h}$-channels in the retina which are structurally similar and have similar properties. It is thought that ivabradine inhibits hyperpolarisationactivated current in retinal cells $\left(\mathrm{I}_{h}\right)$ preventing the normal filtering out of random visual sensations that can be generated in the retina. These are known as phosphenes and can cause visual disturbances. ${ }^{52}$ Trial data indicate that phosphenes were transient, occurred mainly in the first month of treatment, under welldefined conditions such as light variation and were well tolerated. ${ }^{44,49,53}$ Luminous phenomena were reported by $14.5 \%$ of patients but fewer than $1 \%$ of patients changed their daily routine or discontinued the treatment in relation to phosphenes. $^{37}$
Sinus bradycardia is an expected pharmacological effect of ivabradine and is proportional to the resting heart rate. It occurs at rest and during exercise due to the slowing of the sinus node discharge by selective inhibition of the $I_{f}$ current. The incidence of sinus bradycardia was similar to reported levels with $\beta$-blockers, being 2.2 and $5.4 \%$ of patients receiving 7.5 and $10 \mathrm{mg}$ ivabradine respectively compared to $4.3 \%$ of patients receiving atenolol. ${ }^{44}$ In another study, less than $1 \%$ of patients withdrew because of sinus bradycardia. There was no evidence for association of sinus bradycardia with aggravation of other arrhythmias..$^{54,55}$

There was no evidence of rebound effect with drug cessation or pharmacological tolerance with long-term use. ${ }^{42,44,49}$

Slowing the heart rate by ivabradine is associated with prolongation of the QT interval in a dose-dependent manner. A long term study where the QT interval was evaluated using a population corrected formula showed absence of change in corrected QT interval throughout follow-up supporting lack of direct effect of ivabradine on ventricular repolarisation. ${ }^{55,56}$

A review of adverse effects of ivabradine in trials of clinical efficacy has been presented in the European Public Assessment Report (EPAR 2005) and summarised in Table $8 .^{57}$ 
Table 8. Emergent visual and cardiac adverse events reported by at least $0.5 \%$ of patients exposed to ivabradine 5 or $7.5 \mathrm{mg}$ bid in the O verall O ral Safety set. PY, patient-years. ${ }^{57}$

\begin{tabular}{|c|c|c|c|c|c|c|c|c|c|c|c|c|}
\hline \multirow[t]{2}{*}{$\begin{array}{l}\text { System organ class } \\
\text { Preferred term }\end{array}$} & \multicolumn{3}{|c|}{$\begin{array}{c}\text { Ivabradine } \\
\text { (5 or } 7.5 \text { mg bid }) \\
(n=1651) \text { PY }=635.2\end{array}$} & \multicolumn{3}{|c|}{$\begin{array}{c}\text { Placebo } \\
(\mathrm{n}=313) \mathrm{PY}=64.7\end{array}$} & \multicolumn{3}{|c|}{$\begin{array}{c}\text { Atentolol } \\
(n=408) \text { PY }=184.4\end{array}$} & \multicolumn{3}{|c|}{$\begin{array}{c}\text { Amlodipine } \\
(\mathrm{n}=404) \mathrm{PY}=95.5\end{array}$} \\
\hline & $\mathbf{n}$ & $\%$ & PY & $\mathbf{n}$ & $\%$ & PY & $\mathbf{n}$ & $\%$ & PY & $\mathbf{n}$ & $\%$ & PY \\
\hline Eye disorders & 281 & 17.0 & 44.24 & 10 & 3.2 & 15.46 & 39 & 9.6 & 21.15 & 19 & 4.7 & 19.90 \\
\hline Visual disturbance NOS & 270 & 16.4 & 42.51 & 9 & 2.9 & 13.91 & 27 & 6.6 & 14.64 & 18 & 4.5 & 18.85 \\
\hline Cardiac disorders & 296 & 17.9 & 46.60 & 29 & 9.3 & 44.82 & 62 & 15.2 & 33.62 & 53 & 13.1 & 55.50 \\
\hline Sinus bradycardia & 53 & 3.2 & 8.34 & 3 & 1.0 & 4.64 & 21 & 5.1 & 11.39 & 7 & 1.7 & 7.33 \\
\hline Ventricular extrasystoles & 50 & 3.0 & 7.87 & 4 & 1.3 & 6.18 & 5 & 1.2 & 2.71 & 11 & 2.7 & 11.52 \\
\hline Angina pectoris aggravated & 33 & 2.0 & 5.20 & 6 & 1.9 & 9.27 & 7 & 1.7 & 3.80 & 4 & 1.0 & 4.19 \\
\hline Angina unstable & 33 & 2.0 & 5.20 & 1 & 0.3 & 1.55 & 1 & 0.2 & 0.54 & 5 & 1.2 & 5.24 \\
\hline Atroventricular block 1st-degree & 23 & 1.4 & 3.62 & 3 & 1.0 & 4.64 & 8 & 2.0 & 4.34 & 2 & 0.5 & 2.09 \\
\hline Myocardial ischemia & 19 & 1.2 & 2.99 & 3 & 1.0 & 4.64 & 6 & 1.5 & 3.25 & 2 & 0.5 & 2.09 \\
\hline Palpitations & 15 & 0.9 & 2.36 & 0 & 0.0 & 0.00 & 1 & 0.2 & 0.54 & 3 & 0.7 & 3.14 \\
\hline Supraventricular extrasystoles & 15 & 0.9 & 2.36 & 4 & 1.3 & 6.18 & 2 & 0.5 & 1.08 & 2 & 0.5 & 2.09 \\
\hline Atrial fibrillation & 15 & 0.9 & 2.36 & 1 & 0.3 & 1.55 & 2 & 0.5 & 1.08 & 5 & 1.2 & 5.24 \\
\hline Myocardial infarction & 13 & 0.8 & 2.05 & 1 & 0.3 & 1.55 & 2 & 0.5 & 1.08 & 3 & 0.7 & 3.14 \\
\hline Ventricular tachycardia & 11 & 0.7 & 1.73 & 0 & 0.0 & 0.00 & 0 & 0.0 & 0.00 & 0 & 0.0 & 0.00 \\
\hline Supraventricular tachycardia & 8 & 0.5 & 1.26 & 1 & 0.3 & 1.55 & 0 & 0.0 & 0.00 & 2 & 0.5 & 2.09 \\
\hline
\end{tabular}

\section{KEY POINTS}

- Ivabradine is a selective and specific inhibitor of the If current which regulates sinoatrial pacemaker activity.

- Antianginal and antiischemic efficacy is based on heart rate reduction without any effect on myocardial contractility, ventricular repolarisation or cardiac conduction.

- Twice daily administration for two weeks lowers resting heart rate, improves exercise tolerance and time to limiting angina during exercise and reduces the frequency of angina attacks in patients with chronic stable angina.

- Efficacy of ivabradine is non-inferior to the b-blocker atenolol and the calcium channel-blocker amlodipine.

- Maximal efficacy is evident within the first four weeks of treatment and is maintained for at least one year.

- Ivabradine has a good safety profile and well tolerated, with mild visual symptoms being the most widely reported side-effects.

\section{REFERENCES}

1. Guidelines on the management of stable angina pectoris: executive summary. The Task Force on the Management of Stable Angina Pectoris. Eur Heart 7 2006; 2: 1341-81

2. Steg PG, Himbert D. Unmet needs and therapeutic opportunities in stable angina, Eur Heart f Suppl 2005; 7:H7H15.

3. Kannel WB, Kannel C, Paffenberger RS et al. Heart rate and cardiovascular mortality: the Framington study. Am Heart f 1987; 113: 1489-1495.

4. Levine HJ. Rest heart rate and life expectancy. 7 Am Coll Cardiol 1997; 39: 1104-106.
5. Diaz A, Bourassa MG, Guertin MC et al. Long-term prognostic value of resting heart rate in patients with suspected or proven coronary artery disease. Eur Heart $\mathcal{f}$ 2005; 26: 967-74.

6. Fox K, Borer JS, Camm J, MD, Danchin N, et al. Resting Heart Rate in Cardiovascular Disease. $7 \mathrm{Am}$ Coll Cardiol 2007; 50:823-30.

7. Feringa HH, Bax JJ, Boersma E et al. Resting heart rate and its changes over years as a risk factor for mortality in the general population: the Paris Prospective Study Circulation. 2006; 114 (suppl I): I344-49.

8. Cook S, Togni M, Schaub MC et al. High heart rate: a cardiovascular risk factor? Eur Heart $f$ 2006; 27: 2387-93. 
9. López-Sendón J, Swedberg K, McMurray J et al. Expert consensus document on b-adrenergic receptor blockers. The Task Force on Beta-Blockers of the European Society of Cardiology. Eur Heart 7 2004; 25: 1341-62.

10. Weber M. The Role of the New-Blockers in Treating Cardiovascular Disease. Am 7 Hypertens 2005; 18:169S176S.

11. Thackray SD, Ghosh JM, Wright GA, Witte KK et al The effect of altering heart rate on ventricular function in patients with heart failure treated with beta-blockers. $\mathrm{Am}$ Heart 7. 2006; 152: 713

12. Cucherat M. Quantitative relationship between resting heart rate reduction and magnitude of clinical benefits in post-myocardial infarction: a meta-regression of randomised clinical trials. Eur Heart 7 2007; 28: 3012-19

13. DiFrancesco D, Camm JA. Heart rate lowering by specific and selective I(f) current inhibition with ivabradine. Drugs 2004; 64: 1757-65.

14. Cargnoni A, Ceconi C, Stavroula G Ferrari R. Heart rate reduction by pharmacological If current inhibition. $A d v$ Cardiol 2006; 43: 31-44.

15. Ferrari R Cargnoni A, Ceconi C. Anti-ischaemic effect of ivabradine. Pharmacol Res 2006; 53: 435-9.

16. Shattock M, Camm AJ. Pure heart rate reduction: the $I_{\mathrm{f}}$ channels from discovery to therapeutic target. $\mathrm{Br} \mathcal{F}$ Cardiol. 2006;13: 27-35.

17. Tardif J-C. Ivabradine in clinical practice: benefits of If inhibition. Eur Heart f Suppl 2005; 7: H29-H32

18. DiFrancesco D, Tromba C, Inhibition of hyperpolarisationactivated current (If) induced by acetylcholine in rabbit sinoatrial node myocytes. 7 Physiol 1988; 405: 477-491.

19. DiFrancesco D The contribution of the "pacemaker" current (If) to the generation of spontaneous activity in rabbit sinoatrial node myocytes. F Physiol 1991; 434: 23-40.

20. Bois P, Bescond J, Renaudon B, Lenfant J. Mode of action of bradycardic agent, S 16257, on ionic currents of rabbit sinoatrial node cells. Br F Pharmacol 1996;118:1051-57.

21. Thollon C, Cambarrat C, Vian P et al. Electrophysiological effects of S16257, a novel sino-atrial node modulator, on rabbit and guinea pig cardiac preparations: Comparison with UL-FS 49. Br F Pharmacol 1994; 112: 37-42.

22. Mangoni ME, Marger L, Nargeot J. If current inhibition: cellular basis and physiology. Adv Cardiol 2006; 43: 17-30.

23. DiFrancesco D. Cardiac pacemaker If current and its inhibition by heart rate reducing agents, Curr Med Res Opin 2005; 21: 1115-22.

24. Colin P, Ghaleh B, Hittinger L, et al. Differential effects of heart rate reduction and beta-blockade on left ventricular relaxation during exercise. Am 7 Physiol Heart Circ Physiol. 2002; 282: H672-679.

25. Colin P, Ghaleh B, Monnet X et al. Contributions of heart rate and contractility to myocardial oxygen balance during exercise. Am f Physiol Heart Circ Physiol. 2003; 284: H676-82.

26. Simon 1, Ghaleh B, Puybasset 1 et al. Coronary and hemodynamic effects of S16257, a new bradycardic agent, in resting and exercising conscious dogs. F. Pharmacol Exp Ther 1995; 275: 659-66.

27. Bel A, Perrault LP, Faris B et al. Inhibition of the pacemaker current: a bradycardic therapy for off-pump coronary operations. Ann Thorac Surg 1998;66:148-52.
28. J.P. Vilaine, C. Thollon, N. Villeneuve, Peglion JL. Procoralan, a new selective /f current inhibitor. Eur Heart Journ (Suppl) 2003; 5: G26-35.

29. Du XJ, Feng X, Gao XM et al. If channel inhibitor ivabradine lowers heart rate in mice with enhanced sympathoadrenergic activities. Br f Pharmacol 2004; 142: 107-12.

30. Berdeaux A. Preclinical results with I(f) current inhibition by ivabradine. Drugs 2007; 67 (Suppl) 2:25-33.

31. Rageuneau I, Laveille C, Jochemsen R et al. Pharmakokinetic-pharmacodynamic modeling of the effects of ivabradine, a direct sinus node inhibitor on heart rate in healthy volunteers. Clin Pharmacol Ther 1998; 64: 192-203.

32. Lucats L, Ghaleh B, Colin $\mathrm{P}$ et al. Heart rate reduction by inhibition of If or by beta-blockade has different effects on postsystolic wall thickening. Br F Pharmacol 2007:150: 33541.

33. Lucats L, Ghaleh B, Monnet X, et al. Conversion of post-systolic wall thickening into ejectional thickening by selective heart rate reduction during myocardial stunning. Eur Heart f. 2007; 28: 872-879.

34. Monnet X, Ghaleh B, Colin P et al. Effects of heart rate reduction with ivabradine on exercise-induced myocardial ischaemia and stunning. F Pharmacol Exp Ther. 2001; 299: 1133-39.

35. Monnet X, Colin P, Ghaleh B et al. Heart rate reduction during exercise-induced myocardial ischaemia and stunning. Eur Heart 7 2004; 25: 579-86

36. Joannides R, Moore N, Iacob M, et al, Comparative effects of ivabradine, a selective heart rate-lowering agent, and propranolol on systemic and cardiac haemodynamics at rest and during exercise.Br 7 Clin Pharmacol 2005;6:127-37

37. Servier Laboratories Ltd. Procoralan, Summary of product characteristics. Sourced from the electronic Medicines Compendium www.emc.medicines.org.uk. Last update May 2007

38. Moore N, Joannides R, Iacob M et al. Effects of a pure bradycardic agent, S 16257, at rest and during exercise in healthy volunteers: comparison with propranolol. Br 7 Clin Pharmacol 1998; 45: 188-89.

39. Duffull SB, and Aarons L. A Development of a sequential linked pharmacokinetic and pharmacodynamic simulation model for ivabradine in healthy volunteers. Eur f Pharm Sci 2000; 10: 275-84.

40. Portolés A, Calvo A, Terleira A, Laredo L et al. Lack of pharmacokinetic interaction between omeprazole or lansoprazole and ivabradine in healthy volunteers: an openlabel, randomized, crossover, pharmacokinetic interaction clinical trial. 7 Clin Pharmacol. 2006; 46: 1195-203.

41. Portolés A, Terleira A, Calvo A et al. Effects of Hypericum perforatum on ivabradine pharmacokinetics in healthy volunteers: an open-label, pharmacokinetic interaction clinical trial. 7 Clin Pharmacol 2006; 46: 1188-94.

42. Borer JS, Fox K, Jaillon P, Lerebours G. Antianginal and Antiischemic Effects of Ivabradine, an If Inhibitor, in Stable Angina. A Randomized, Double-Blind, Multicentered, Placebo-Controlled Trial. Circulation 2003; 107: 817-23.

43. Fox K. Ivabradine - a selective and specific If inhibitor: efficacy and safety in stable angina. Eur Heart Journ Suppl 2003; 5: G36-45 
44. Tardif JC, Ford I, Tendera M et al. Efficacy of ivabradine, a new selective If inhibitor compared with atenolol in patients with chronic stable angina. Eur Heart 7.2005; 26: 2529-36.

45. Fox KM, Tardif JC, Ford I, Tendera M, on behalf of the INITIATIVE study investigators. Anti-anginal and antiischemic efficacy of ivabradine - a selective and specific sinus node If current inhibitor - compared to atenolol in elderly patients with chronic stable angina. Heart 2005; 91 (Suppl. 1): A69.

46. Ruzyllo W, Ford IF, Tendera MT, Fox KF. Antianginal and antiischaemic effects of the If current inhibitor ivabradine compared to amlodipine as monotherapies in patients with chronic stable angina. Randomised, controlled, doubleblind, trial. Eur Heart 7.2004; 25:(suppl) Abstr 878/page 138

47. Ruzyllo W, Tendera M, Ford I, and Fox K. Antianginal efficacy and safety of ivabradine compared with amlodipine in patients with stable effort angina pectoris. Drugs. 2007;67:393-405.

48. Lopez-Bescos L, Filipova S, Martos R. Long-term safety and antianginal efficacy of the If current inhibitor ivabradine in patients with chronic stable angina. A oneyear randomized, double-blind, multicentre trial. Eur Heart $\mathcal{f}$ 2004;25 (Suppl):Abstr 876.

49. Lopez-Bescos L, Filipova S, Martos R. Long-Term Safety and Efficacy of Ivabradine in Patients with Chronic Stable Angina. Cardiology 2007;108: 387-396.

50. Fox K. The BEAUTIFUL Study: Randomized Trial of Ivabradine in Patients with Stable Coronary Artery Disease and Left Ventricular Systolic Dysfunction - Baseline Characteristics of the Study Population. Cardiology 2008;1 10 271-282.

51. Fox K, Ferrari R, Tendera M, Steg PG, Ford I; BEAUTIFUL Steering Committee. Rationale and design of a randomized, double-blind, placebo-controlled trial of ivabradine in patients with stable coronary artery disease and left ventricular systolic dysfunction: the morBiditymortality EvAlUaTion of the I(f) inhibitor ivabradine in patients with coronary disease and left ventricULar dysfunction (BEAUTIFUL) study. Am Heart 7 2006; 152: 860-6.

52. Cervetto L, Demontis GC, and Gargini C. Cellular mechanisms underlying the pharmacological induction of phosphenes REVIEW. Br F Pharmacol 2007; 150: 383-390.

53. Fox KM, TardifJC, Ford M, Tendera on behalf of the INITIATIVE study investigators. Anti-anginal and antiischemic efficacy of ivabradine - a selective and specific sinus node If current inhibitor - compared to atenolol in elderly patients with chronic stable angina. Heart 2005; 91 (Suppl): A69.

54. TardifJC, Fox K, Tendera M, Ford I. Absence of rebound phenomenon after abrupt discontinuation of ivabradine, a new selective and specific If inhibitor, in patients with coronary artery disease. Eur Heart 7 2005; 26: 580.

55. Savelieva I, Camm AJ. Absence of direct effects of the If current blocker ivabradine on ventricular repolarization: analysis based on a population heart rate correction formula. 7 Am Coll Cardiol. 2005; (suppl) 1023-272-95A.

56. Savelieva I, Camm A: Novel If Current Inhibitor Ivabradine: Safety Considerations. Adv Cardiol 2006; 43: 79-96

57. European Public Assessment Report (EPAR). Ivabradine hydrochloride- stable angina pectoris. Scientific discussion. EMEA 2005.

\section{Correspondence:}

Stephen I'Anson, Just Medical Media Ltd, 11 Redgrove Park, Cheltenham, Gloucestershire, GL51 6QY, UK.

Email: publisher@justmedicalmedia.com. 
